\title{
The journey of Jephthah's daughter: On spatial cognition, body and language in Judges 11:37
}

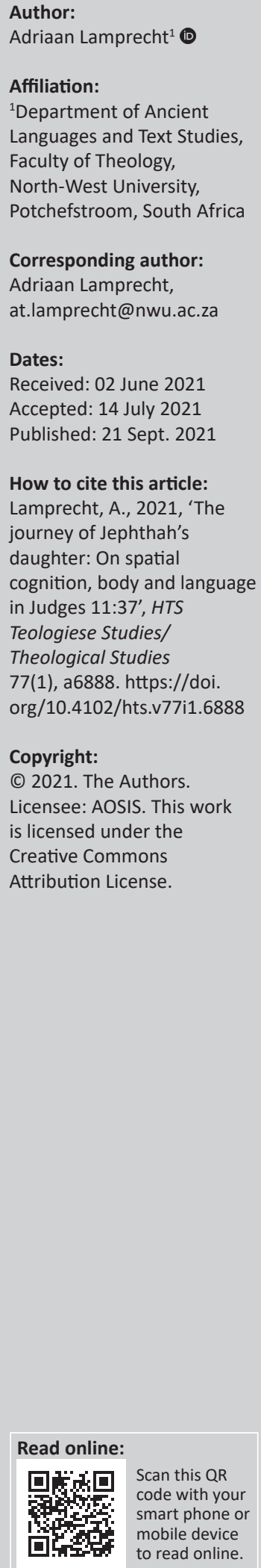

The traditional literal interpretation of the text in Judges 11:37 shows exceptional variation in topographic depiction. The literal interpretation of Driver, published in Zeitschrift für die Alttestamentliche Wissenschaft, is an example. From a linguistic perspective, no attention was paid whatsoever to the relation of interiority between an objective body and an objective space. This article proposes a cognitive semantic perspective and argues that the motion-path verb ירד (yrd) in Judges 11:37 carries a metaphorical meaning, and the linguistic processing, that is, the metaphorical mapping of the image schematic structure of CHANGE (up-down) as the source domain onto that of BEHAVIOUR as the target domain, involving activation of cultural spatial and bodily systems. With this background in mind, Judges 11:37 represents a new understanding for similar UP-DOWN image schemas applied in the Hebrew Bible.

Contribution: This article contributes to the understanding of the apparent 'inexact' sense of the use of ירד (yrd) in Judges 11:37.

Keywords: Judges 11:37; Jephthah's daughter; conceptual metaphor; spatial cognition; Biblical Hebrew; ירז (yrd).

\section{Introduction}

The literal interpretation of Judges 11:37 (example [1]), within the traditional ancient Near Eastern spatial-topographical orientation of 'up' and 'down' (as depicted in traditional dictionaries) (see Holladay 1988:143), evokes for the reader not only a description of an incompatible visual imagery of mental simulation, but differs also in the Bible translators' literal translation of the

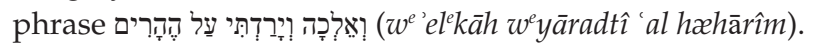

\section{Judges 11:37 (Biblia Hebraica Stuttgartensia [BHS])}

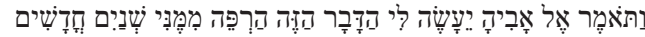

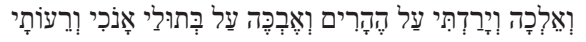

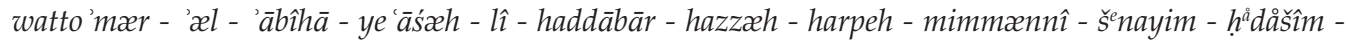
$w^{e}$ 'el'kāh - wee āradtî - 'al - hæhārîm - we'æbkæh - 'al - b'tûlay - 'ānokî - were'ôtāy

The general view of word meaning adopted under literalism (i.e. the notion that word meanings are relatively fixed and stable) is underlying in almost all the bible translations (see Recanati 2004). Consider, for example, the translations of the Luther Bible (LB) [1912], La Sainte Bible (LSB), the American Standard Versions (ASV), the Darby Bible (DBY), the King James Version (KJV), the Old Afrikaans Translation (OAT), the Webster Bible (WEB) and Young's Literal Translation (YLT) (see also Shibayama 1966:358-362). Furthermore, translations recognise the words within their syntactical relation only in terms of their given semantic context as defined in the lexicon. In some translations, the impossibility of a topographically understanding of 'descend upon the mountains'

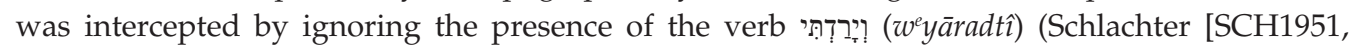
SCH2000], La Bible de Semeur \{BDS\}, The Bible in Basic English [BBE], the New American Standard Bible (1995) [NAB], the New American Standard Bible [1977] (NAS) and the New

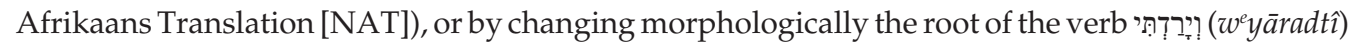

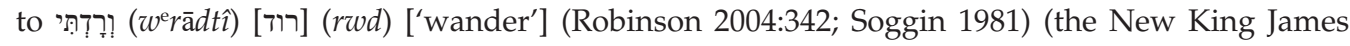
Version [NKJ], the New Revised Standard Version [NRS], the Revised Standard Version [RSV] and Today's English Version [TEV]), or by altering 'the mountains' to become a 'valley'. Bruinses [1844], Liptzin [1985:102-112] and Houtman [2005:167-190] have pointed out that in literature, the

Note: Special Collection: Historical Thought and Source Interpretation, sub-edited by Johann Cook (Stellenbosch University). 
dubious wordplay of this story was recounted, even fictionalised in numerous literary forms.

In his article On עלה 'Went Up Country' and 'Went Down Country', published in Zeitschrift für die Alttestamentliche Wissenschaft, Driver (1957:74-77) explains this 'inexact' or 'peculiar' sense of the use of ירד (yrd) within a topographical depiction. He affirmed '... ירז "went down" may be used of going southwards, i.e. "down country", without reference to the heights involved'. The problem, however, is firstly, that the direction which she wished to take in order to go into the hills is not stated in the text. In bridging this problem, he proposes another solution, and this time again within a topographical depiction, that is (Driver 1957):

Mispah, the name of the place where her family lived, means 'place of outlook', and hence we may infer that the city was situated on some eminence or spur of the Gilead-range overlooking a wide prospect. (p. 75)

Secondly, in biblical Hebrew, only fictional border lines were described using ירד (yrd) for 'southwards' and עלה ('Th) for 'northwards' in navigational space (Lamprecht 2015:169, 198).

The literal language approach towards Judges 11:37 implies that without a specific utterance context, native speakers of English (and the translator of the ancient text) informally define 'went down' as relating to real horizontal motion in a downward direction along the vertical axis. This literal language approach to meaning construction is also evident in, for example, the lexical entry for ירד (yrd) in A Concise Hebrew and Aramaic Lexicon of the Old Testament (Holladay 1988:143):

זירָדז

— I. mostly go down, but occasionally go

up: Ju[dges] 11:37; so also Ju 1:9 15:8 2 K[ings] 2:2

\section{6:18 I C[hronicles]11:15}

This lexical entry illustrates the fatal problem that most dictionaries of biblical Hebrew suffer: the principled separation between context-independent (sentence) meaning and context-dependent (speaker/writer) meaning (De Blois 2000). In almost all biblical Hebrew dictionaries, words are assumed to have meanings connected to them which are context-independent.

However, an analysis of the translations and explanation of Judges 11:37 shows firstly, that the ideal meaning of the verb ירד (yrd) does not itself map directly onto the world and secondly, that the meaning of the verb ירד (yrd) is not an inherent feature of the word-form, that is, fixed and stable. The literal interpretation of the verb ירד (yrd) in Judges 11:37 illustrates the potential problematic position that meanings are context-independent. In addition to this example (1), the following examples (2-6) for the verb ירד (yrd) may also clarify this position.
2. 1 Kings $2: 8$

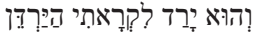

$w^{e} h \hat{u}^{\prime}$ - yārad - liqrā 'tî̀ - hayyarden

... but he came down to meet me (at) the Jordan.

3. Judges 19:11

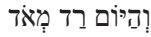

whayyôm - rad - $m^{e}$ 'od

... the day went down much.

4. Genesis 15:11

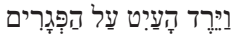

wayyeræd - hā'ayit - 'al - happ geārîm

And the fowls came down upon the carcasses.

5. Joshua 18:16

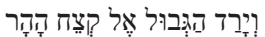

w'yārad - haggebûl - 'æl - q'șeh - hāhār

And the border came down to the end of the mountain.

6. Nehemiah 3:15

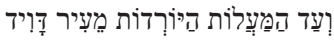

we'ad - hamma'alôt - hayôwordôt - me'îr - dâwîd

... and unto the stairs that go down from the city of David.

In every example, the meaning associated with ירד (yrd) varies across each case of its use. In the first example (2), above and beyond the indication of a change in location (down to a river), the verb ירד (yrd) is also a deictic motion verb (Wilkens 2006:41-42). Motion involves spatial change and change involves time. As opposed to change and motion, in the examples (5) and (6), ירז (yrd) designates spatial configurations. The stairs and border are elongated objects which remain in a steady-state location. Talmy (1996:235287) has labelled examples like these as 'fictive motion'. By this is meant that a static situation is encoded in a way that evokes a sense or a conceptualisation of something in motion. Furthermore, example (5) differs from all the other examples regarding the frame of reference feature: the cardinal point system (north-east-south-west) is a set which includes the word form ירד (yrd) meaning 'down' (see also Nm 34:11, 12; Jos 15:10; 16:3, 7; 17:9; 18:13, 17, 18; Jdg 15:8, 11, 12; 1 Chr 11:15; 1 Sm 22:1; 23:13, 25; 2 Sm 5:17; Jr 22:1). In example (4), the verb ירד (yrd) in context clearly points to the 
manner of motion as well, for example, fly. Moreover, the context dependence of ירד (yrd) is even more marked if we consider uses that are, intuitively, more figurative in nature as in (3).

What examples such as those in (2-6) illustrate is that the verb ירד (yrd) provides access to a diverse array of encyclopaedic knowledge involving distinct movements in distinct spatial categories, agents, actions and events. This implies that a word such as ירד (yrd) appears to be changeable in nature: it has a meaning potential, and dependent on the context of its use.

A large number of Cognitive Linguists (Evans 2009; Lakoff 1987; Tyler \& Evans 2003) and biblical Hebrew scholars (e.g. De Blois 2000) have argued that the principled separation of context-independent and context-dependent meaning is illusory. These scholars have shown that the meaning of a given word, and hence the valid interpretation of the sentence to which the word contributes, is typically a function of contextual knowledge. So, the received view of literalism as an approach to meaning-construction in Judges 11:37 must be revised.

The hypothesis of this study is that, in Judges 11:37, there is an intermediate level of spatial conceptualisation, where an image schematic function maps a motion-path description onto a spatial category. The spatial category determines the extent that the verb ירד (yrd) contributes to the meaning of Judges 11:37. The way that a motion relates to a space will depend on the category of space, that is, topography, worldview, body and objects (Lamprecht 2015:89-132).

The alternative understanding on the nature of word meaning proposed by Lakoff (1992:4) when he says that as 'soon as one gets away from concrete physical experience and starts talking about abstractions or emotions, metaphorical understanding is the norm', hardly comes to mind in any translation, commentary or literary study on this verse. This alternative view motivates the hypothesis that there is an intermediate level of spatial conceptualisation, where an image schematic function maps a motion-path description onto a spatial category and implies that the words

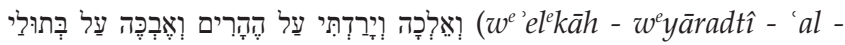
hæhârîm - we' $x b k æ h$ - 'al - b'tûlay) were not used in their 'normal everyday senses'. Spronk (2019:350), in his recent commentary on Judges, also admits the 'strange' use of the verb ירד (yrd) in this verse, but does not explain the linguistic processing of the sentence. Therefore, this hypothesis focusses on the linguistic processing of the verb ירד (yrd) and requires a closer look at the relation of interiority between an objective body and an objective space within biblical Hebrew language use.

Within the Cognitive Semantic approach to the study of language, the traditional view that meaning derived from the literal interpretation of the words in an expression becomes inadequate, and what is necessary to understand the nonmetaphorical (literal) and metaphorical meaning of words is a theory of background information and language usage.

\section{A Cognitive Semantic approach towards language}

The guiding assumption of Cognitive Semantics is that human language cannot be properly understood without taking into account the ways in which human cognition functions (Langacker 1987:12). Therefore, this methodology relates language to conceptualisation and human experience. Experientialism is used:

$[T]$ o describe the philosophical view that linguistic meaning cannot be described independently of the nature and experience of the organisms doing the thinking. Conceptual structure is meaningful because it comes from and is linked to the human perceptual system, which entails his pre-conceptual experience. (Barcelona 1997:9)

Meaning is seen as residing in conceptualisation. So, for experientialists, meanings do not exist independently (Lakoff 1987) from the people who create and use them (Reddy 1979:284-324). This means that 'all linguistic forms do not have an inherent form in themselves; they rather act as clues activating the meanings that reside in our minds and brains' (Barcelona 1997:9). Meaning is, therefore, not tidily contained in the lexicon, but ranges all through the linguistic spectrum. Meaningfulness involves the structuring of experience itself (Lakoff 1987:302). As most neurolinguistic research on the mental structuring model emphasises the neurological organisation, it tends to ignore the importance of people's ordinary, kinaesthetic experience which is 'structured in part by the nature of the bodies that humans have' (Gibbs 2003:2). This means that 'people's subjective, felt experiences of their bodies-in-action provide part of the fundamental grounding for language and thought' (Gibbs 2003:3). Thus, language and thought are inextricably shaped by embodied action and therefore meaning must be embodied.

The shift from the view that a word is 'a minimal permutable element' (Cruse 2004:85) à la the classical characterisation to 'meanings as mental and embodied' (Lakoff 1987:xi) brings about an alternative approach towards meaning (Croft \& Cruse 2004:97). So, Cognitive Semantics adopts an experientialist perspective, which means that 'it is concerned with the relationship between (embodied) experience, the conceptual system, and the semantic structure encoded by language' (Croft \& Cruse 2004:97).

A fundamental aspect of human cognition is our ability to embody events that capture, amongst others, our spatial experiences in the world (Lakusta \& Landau 2005:1). For this reason, space forms part of the bedrock of the human's cognitive architecture. Consequently, the study of spatial conception of the body in the Hebrew Bible is important as the non-linguistic representation of objects or structures, motions, paths and spatial-causal relationships that are mapped onto words reveals the hidden complexities of the ancient Israelites' mind and how dependent their alleged world was 'on the nature and organisation of the cognition which happened to evolve in a human body' (Evans 2009:15). 


\section{Spatial conception of the body}

One of the most important findings in Cognitive Science is that the mind, brain and body interact to construct the human's experience of space (Rohrer 2007:340). This implies that cognition, space and body are interrelated and must be studied as such. Spatial knowledge comprises conceptual knowledge of, inter alia, human bodies (physiological) to be identified by their spatial properties. These spatial properties or dimensions include, inter alia, 'the gradable characteristics of their typical, possible or actual extensions in space' (Lang, Carstensen \& Simmons 1991:1).

In his study on Phenomenology of Perception, Merleau-Ponty $(1962: 99,148)$ describes the 'relation between body and space not as a relation of interiority between an objective body and an objective space in which the former is located'. Beneath objective space, there is rather a 'spatiality... which merges with the body's very being. To be a body, is to be tied to a certain world; our body is not primarily in space: it is of it'. Our body thus 'inhabits' space (and time). Bodily attributes and images are transposed on to space and to the objects that occupy it. This implies an extension of space: the body incorporates the experiences of the social and cultural body as well. Spatial extension is, generally speaking, the property of 'taking up space'. The idea of an increase in length can be seen in quantity, for example, hairs grow, tears roll down, bodily parts grow (from a baby to an adult), etc. These quantities vary according to the dimensions assigned to the body. The semantic form representations of the quantities vary from length (long-short), width (wide-narrow), substance (thick-thin), distance (wide-narrow), vertical (high-low) to size (big-small). Knowledge of these extensions is acquired by means of a seamless connection between the virtual and the physical space (Hwang, Kim \& Rizzo 2004:292). So, movement in bodily space is threefold: Firstly, human bodies are usually in an upright position: the head is up and feet are down. Moreover, the complete human body is an area on which water or oil 'goes down' from top to bottom. The downward path of the movement of oil or water on a body is because of the erect posture and gravity. Therefore, movement on a human body includes the spatial experience of movement from a higher locality to a lower locality on the body's up-down shape. Secondly, humans drink water, eat food, etc., which means that the body is also a container of food, water, blood, etc. The physical experience of a container is, if you add more of a substance to a container, the level goes up and vice versa. Thirdly, a human body itself is able to move downwards, that is, to bend, to trample with feet or to hit something or someone with the hand. One of the great achievements in Cognitive Linguistic research is the finding that these perceptual components are stored in image schematic fashion. The asymmetry of up versus down and the experience of spatial extensions and movement in bodily space resulted, inter alia, in the image schematic structure of CHANGE.

The ancient Israelites who lived 3000 years ago had bodies, just like we do as human beings. On comparing these two 'bodies' on the time continuum, it is clear that not much has changed physically (De Joode 2014:554-567; Lakoff \& Johnson 1980:29-30). So, the thesis made by Rohrer (2007:360) that the body (along with other dimensions) grounds and shapes human cognition, it is concomitantly just as applicable to the ancient Israelites' bodies as to our modern bodies. The fact that bodies shape and constrain how humans think in multiple dimensions is also applicable to biblical Hebrew literature (Kruger 2000:185). So, the body, cognition and language are perceptually situated in social and cultural practices (Sinha \& Jensen de López 2000:17-41).

The interaction of the ancient Israelites' bodies with the environment plays a decisive role in how categories of the mind are defined. The importance of the image schemas, as argued by Lakoff (1987) and Johnson (1987), lies in the fact that they are cognitively more primitive than the conceptual structures. To the ancient Israelites, the image schemas UPDOWN and CONTAINER were structures which interpreted and framed their experiences. These embodied schemas of concrete objects and situations were employed to make sense of more abstract entities and events.

\section{Understanding abstract concepts - Judges 11:37}

Schemas usually extend into a conceptual world of abstraction. While a perception of a scene is usually rich in detail, imagistic abstract concepts are not nearly as detailed as perceptions and do not have specific knowledge associated with them. They are rather one of the fundamental facilities through which people make sense of the world and they help provide meaning to experience and understanding to knowledge. So, imagination is (1) 'the faculty of imagining, or of forming concepts of what is not actually present to the senses' and (2) 'the action or process of forming such concepts' (Norman 2000:1-2). More specifically then to the ancient Israelites' spatial experience, image schemas appear by virtue of analysing spatial displays of various sorts as related to the functional consequences with which they are correlated.

The ability to make the spatial experience accessible to the conceptual system by representing it as concepts comprises the cognition part of the representational system. Taking into account the perceptual and spatial experience to which the ancient Israelites were exposed, schematic memories of spatial representations (reflected as spatial organisational and structured image schematic concepts) can be derived.

The notion of human behaviour, an abstract concept, is highly amenable to metaphoric extension in languages and biblical Hebrew is no exception. The preconceptual structure or image schema directly meaningful to the ancient Israelites enabled them to organise their conceptualisation of bodily space and appears to outline the UP-DOWN schema. Consider Isaiah 15:2-3 (example [7]): (I accept the BHS text-

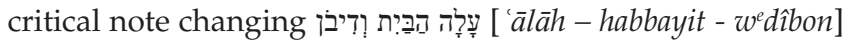

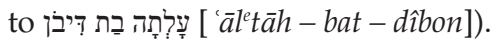


7. Isaiah $15: 2 \ldots$

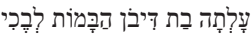

'àletāh-bat - dîbon - habbāmôt - l'bækî̀

'she went up (spatial + motion) - the daughter of Dibon - to the heights (spatial) - to weep'

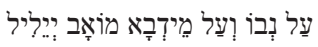

'al - n'bô- $w^{e}$ 'al $-m e \hat{e} d^{e} b \bar{a}^{\prime}-m \hat{o}{ }^{\prime} \bar{a} b-y^{e} y e l \hat{\imath} l$

... upon (spatial) Nebo and upon (spatial) Medeba - Moab cries bitterly

Thus far in this example (7), the organised subdomains operate normally in form and meaning in that topological features in theabsolutespatial direction are theinterpretational type. The located goal is the endpoint. An analysis of the

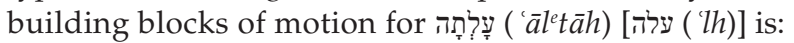

Figure: Human

Source: Topographically lower region

Goal: Topographically higher location/near God (Peleg 2013:109-115)

Spatial part: Horizontal: high

Motion: Translocative, unbounded

The first part of the next verse (verse 3) (example [8]) links up with the previous verse (verse 2 ) in terms of the organisation of the subdomains, but the remainder of the verse (yored babbrkî) employs a different spatial direction (bodily), as well as a different frame of reference (space of the body). The motion is fictive, non-translocative and bounded:

\section{Isaiah $15: 3$}



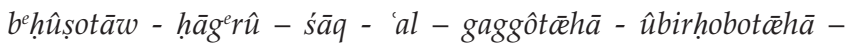
kulloh - yeyelîl

Upon (spatial) their streets - they dressed - (in) sackcloth

Upon (spatial) her house-tops (spatial) - and on her city squares - everyone cried bitterly

יררִד בַּבְכִי

yored babbækî

Going down (spatial + motion) in weeping

An analysis of the building blocks of motion for (yored) (ירז [yrd]) is:

Figure: Human (behaviour)

Source: Abstract concept: State of gladness

Goal: State of sadness
Spatial part: Vertical: bottom

Motion: Fictive: non-translocative, bounded

Lakoff and Kövecses (1987:195-221) indicate that 'the body is a container for emotions'. The effect of this is observable: the human body usually reflects its emotional stand (Lakoff \& Johnson 1980:20). For example, an erect posture typically accompanies a positive emotional state, while a drooping posture typically reflects sadness and depression. Mourning may also form a part of the liminal phase characterised by passiveness: the person usually sits on the ground in a passive posture (Kutsch 1965). However, humans may differ by employing different gestures or bodily attitudes to express a certain emotion or communicate a particular message. Take the common body language of nodding (vertically) which is almost universally an indication of agreement or subtle subservience (a form of bowing or making oneself lower in status). In this example (8), GOING DOWN (רד [yrd]) IN WEEPING is experientially linked with the network for behaviour. The downward movement of the body designates a change in emotional state from positive (an erect posture) to negative (a drooping posture). The underlying knowledge structure is the UP-DOWN orientation and the static 'path: under' points to the emotional stand. The following basis of the conceptual metaphor SADNESS IS DOWN in this verse can be derived:

Metaphorical expression: He goes down in weeping.

Source domain: Movement in bodily space

Target domain: Sadness

Binary structure: UP-DOWN

Conceptual metaphor: GLADNESS IS AN ERECT POSTURE OR SADNESS IS DOWN

This psychological view is supported by Sutskover (2014:205) who argues that movement in space, and the mention of characters' positions may symbolise the characters' psychological state.

So, from this example, it seems that when someone fulfils an act of mourning, he or she usually 'goes up' to a higher place (topology) which is non-fictive, translocative and unbounded, probably in mourning near the deities, but the act of mourning was a negative experience in that weeping was an act of 'going down' (bodily space). The latter is fictive motion, non-translocative and bounded. This is then an example of a complex mix of orientation and functional criteria within the ancient Israelite's grammatical structures to express meaning.

Moreover, in logical categorisation, two logical concepts are included under the next higher category as their genus proximum, and maintain their distinctive characters, viz.:

Superordinate level: ritual 企令 
Basic level:

今

Subordinate level:

mourn

令

wail, put on sackcloth

That the superordinate concept is a necessary condition for the subordinate one is a necessary condition for the derivation of meaning. A ritual is not something objective in the world independent of any being; it is rather what Lakoff (1987) refers to as:

$[A] n$ interactional property - the result of our interactions as part of our physical and cultural environments given our bodies and our cognitive apparatus. Such interactional properties form clusters in our experience, and prototype and basic-level structure can reflect such clusterings. (p. 51)

\section{Lakoff (1987) explains it further by saying that:}

$[B]$ asic-level categories are human-sized in that they depend not on objects themselves, independent of people, but on the way people interact with objects: the way they perceive them, image them, organise information about them, and behave toward them with their bodies. (p. 51)

Thus, basic-level categories have different properties from superordinate categories. For example, superordinate categories seem not to be characterised by images or actions. For example, we have mental images of mourning - abstract images that do not fit any particular mourning - and we have general actions for being 'dressed in sackcloth'. But if we go from the basic-level category MOURN to the superordinate category RITUAL, a difference emerges. We have no abstract mental images of rituals that are not images of basic-levels like mourn, cry, shout, etc. People seem not to be able to imagine a more abstract object for RITUALS that does not seem like mourning, crying or shouting, etc.

So, the category RITUAL becomes a metonymic principle for the act of mourning, in this verse ירָּ (yored babbxkî) ('going down in weeping'). This implies that the psychological effects of behaviour stand for the behaviour (Lakoff 1987:382). Mourning has the psychological effect of 'go down', and therefore stands for the behaviour. As a result, the expression

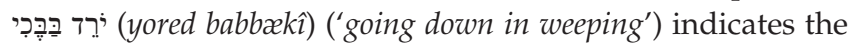
presence of RITUAL and MOURN via its supposed psychological or bodily effects. As a final point, when describing experiences such as emotional insecurity, the Hebrew Bible uses the spatial concept of motion as well as the image schematic structure of CHANGE (up-down) as the path. Rosenberg (1987:102), as echoed by Spronk (2019:350), also makes an effort to link the two texts (Jdg 11:37; Is 15:3), but with no reference to the linguistic processing of the abstract concepts involved.

In the experientialist approach to the mind, the world is 'created' or built up by the mind in several imaginative ways. The imaginative ways include such cognitive processes as categorisation based on prototypes and understanding experience through metaphors. Consider again the example (8) (Is 15:3): This example designates an event in the domain: change of state of behaviour. In the Lakovian sense, we might say that the expression 'going down in weeping' illustrates a change of state and is metaphorically construed in terms of an experientially more basic domain, change of location (although fictive and non-translocative, but bounded). Thus, in this example, the human behaviour 'goes down' from one metaphorical location (the state of being glad) to another metaphorical location (the state of being sad). The conceptual metaphor SADNESS IS DOWN or A LESS DESIRABLE STATE IS DOWN implies that reason has a bodily basis, and that the space of the body frame of reference is applied.

Let us turn to the example (1) in Judges 11:37. What will the prototype of the verb ירז (yrd) be in which the cognitive process of categorisation functions? The original impetus for Cognitive Linguistics came from the pioneering research of psychologist Eleanor Rosch on the nature of human categorisation (Rosch 1973a:328-50, 1973b:111-44, 1978:27-48). According to this research, the minds of human beings tend to assign everything that is perceived in the world around us into categories. Categories are not universal, but depend on the experiences, beliefs and cultural practices of a certain group. Different people may perceive the world around them in varying ways, which will be reflected in different categories.

Applied to the text in Judges 11:37, the categories and operations for structuring the linguistic expression

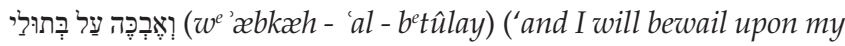
virginity') are as follows:

\section{Category $\Rightarrow$ axiality $\Omega$ \\ Notions $\Rightarrow$ directed shif $=$ emotional insecurity

$$
\Rightarrow \text { endpoint }=\quad \begin{aligned}
& \text { restoration of emotional } \\
& \text { stability or joy }
\end{aligned}
$$

These operations are derived from the ritual of sacred promiscuity underlying the narrative of Jephthah's daughter (Gur-Klein 2003:20, 29). The story brings to the surface a few different but analogous significant niceties. In order to gain social honour amongst the ancient Israelites after been forced to leave home, Jephthah is, on the one hand, the outsider in space in relation to Gilead (Israel), which embodies the inside. On the other hand, יהוה (Yhwh) is the outsider in space in relation to Jephthah's house to bring divine blessing upon Jephthah's vow to the war against the Ammonites and inherently fertility to the whole of Israel. The suffering participant in the end is not only the son of a prostitute, but also his only and virgin daughter. Jephthah won the fight, but it was for a short while: Jephthah's house was under siege: Jephthah's daughter became a 'sacrifice' to a divinity, an act of sacred promiscuity. 'Common to sacrifices is the desire to forgo personal claims for the sake of the gods, which usually concerns pleasure: food, possession and/or women' (Gur-Klein 2003:20). Apart from the social honour, the function of the outsider in these cults was to bring divine blessing and fertility (Bal 1988). The 'sacrifice' of a virgin 
daughter to the temple of the goddess of fecundity underlines a permuting custom. Excess is the equivalent of propitiatory sacrifice, and 'sexual continence and sexual promiscuity were closely linked, both requiring the forfeiting of individual rights for the sake of the gods' (Briffault 1927:202). This ritual has its origin in a frame in which the natural order of life in the ancient Near East assigned particular roles to each person whether from a specific status or gender. So, 'once a person had managed to survive childhood, the expectation was that he/she would become a contributing member of the household and the community' (Briffault 1927:216-217). In this sense, Stol (1995) notes that:

[T] he Sumerian Hymn to Gula includes the following stages of a woman's life: I am daughter, I am bride, I am spouse, I am housekeeper. Thus all members had tasks to perform in managing their lives of those who depended upon them. (pp. 287-297)

But, the daughter of Jephthah was going to die unmarried and childless - indeed, a forfeit of life's enjoyment (see also Keddell 1840:77; Wood 1975:290). Moreover, the act of mourning was a very negative experience for a woman. When the sackcloth was put on around the waist and below the breasts, the shoes (2 Sm 15:30; Ezk 24:17, 23) and the headdress (Ezk 24:17, 23) were taken off, the 'nakedness' (as described in Mi 1:8) of the body was an expression of personal sorrow and shame.

The directed shift on the axiality of the linguistic expression

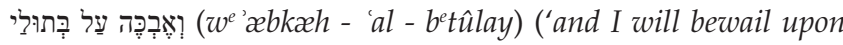
my virginity') towards the fictive endpoint can be described as fictive motion which is located (but non-translocated). This directed shift could be classed amongst the category RITUAL, which is a metonymic principle for the act of mourning. The conclusion in Isaiah 15:3 that mourning has the psychological effect of 'down' is applied in the same way

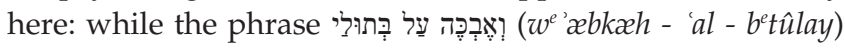
relates to the psychological or bodily effects in the same way

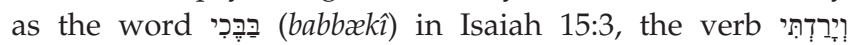
( $w^{e} y \bar{a}$ radt $\left.\hat{\imath}\right)$ describes the emotional experiences of insecurity, using the spatial concept of motion as well as the image schematic structure of CHANGE (up-down) as the path.

The inclusion of a topological feature הָדר (hæhārîm) (the mountains) presupposes a translocative motion of a figure (human) to a location topographically higher or near God (Peleg 2013:109-115). In an isolated structure, this physically located goal may be mistaken as the only endpoint of motion in the sentence. In this verse, however, such is not the case.

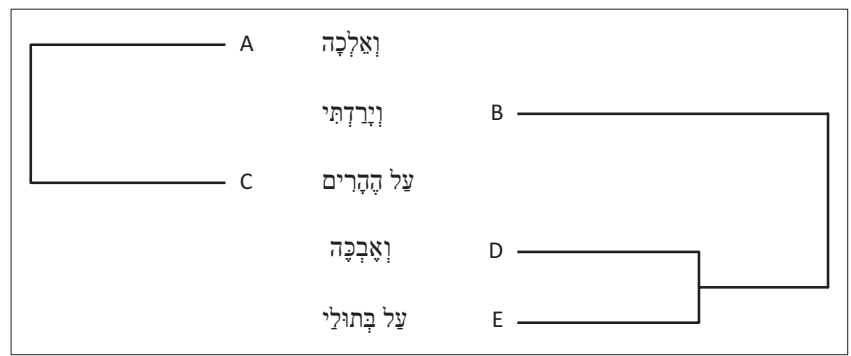

FIGURE 1: Structural relation: Judges 11:37.
The endpoint of motion is rather a dual mix of orientation and functional criteria. Spronk (2019:350, following Sasson 2014:441) just mentions the syntactical topic position of the verb ירז (yrd) between the two cohortatives, without explaining the topicalisation conceptually. So, structurally, the following schema may be applied as shown in Figure 1.

The following distinctive forms and meanings prevail: the conceptual blending of $\mathrm{A}+\mathrm{C}$ in this example embodies the absolute spatial direction with the located goal that is the endpoint. An analysis of the building blocks of motion is:
Figure: Human
Source: Topographically lower region
Goal: Topographically higher location
Spatial part: Horizontal: high
Motion: Translocative, unbounded

In contrast, the conceptual blending of $B+[D+E]$ is an example of the body as spatial direction. The expression

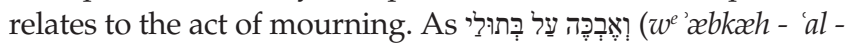
$b^{e}$ tûlay) refers to a non-physical entity which thus cannot undergo vertical motion, the expression 'went down' would appear not to apply in the same way as it does, for example, in 2 Kings 8:29:

\section{2 Kings 8:29}

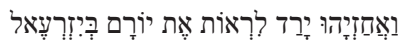

(wa’hazyāhh - yārad - lir'ôt - 'æt - yôrām - beyizre'æ'l)

And Ahaziah went down to see Joram in Jezreel.

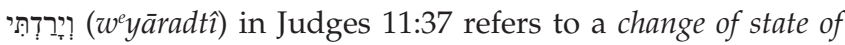
behaviour, from one 'location' (the state of being glad) to another 'location'. Given that 'down' is not being used in a topographically spatial sense, we might informally describe its usage as being non-literal or figurative in nature. This figurative conception 'relates to that part of the semantic potential which is activated during the process of interpretation during the construction of a conception' (Evans 2009:285). Within the cognitive model where BAHAVIOUR is taken to be an instance of an abstract domain, the figurative conception arises when cognitive models are activated in the secondary cognitive model profile. This means that BEHAVIOUR as an abstract domain is structured in terms of content from the more concrete domain, that is SPACE. This implies that we have to do with a unipolar conceptual metaphor.

An analysis of the building blocks of motion concerning the unipolar conceptual metaphor of $B+[D+E]$ is then:

\footnotetext{
Figure: Human (behaviour)

Source: Abstract concept: State of gladness, joy

Goal: State of sadness

Spatial part: Vertical: bottom

Motion: Fictive: non-translocative, bounded
} 


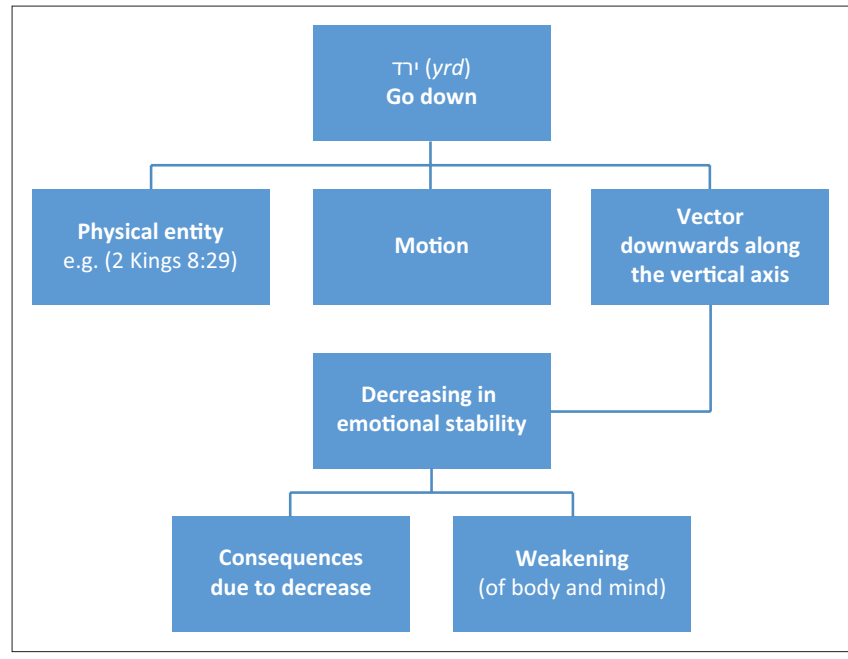

FIGURE 2: Partial cognitive model profile for ירד (yrd).

So, GO DOWN gives access to knowledge relating to a physical entity that is capable of motion, and the motion is directed against gravity on the vertical axis. These represent at least two of the primary cognitive models to which GO DOWN affords access (MOTION and VECTOR DOWNWARDS ALONG THE VERTICAL AXIS). A small number of secondary cognitive models are illustrated (Figure 2). The first relates to the spatial extension DECREASE IN QUANTITY. A further secondary cognitive model concerns the consequences that naturally increase by virtue of less quantity. For instance, the lower the level of water in a jug relates to less ability to have good living conditions. In addition, there is also a secondary cognitive model of WEAKENING which derives from a decrease in quantity. Weakening relates to a CHANGE evaluated as negative, in this instance a decrease in emotional stability.

In the text of Judges 11:37, conflict resolution is achieved by virtue of the secondary cognitive model of WEAKENING, achieving primary activation. This provides a match between the informational characterisation associated with

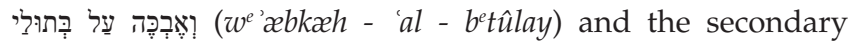

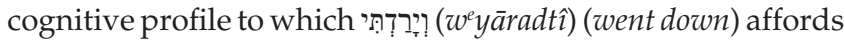
an access. So, this example in Judges 11:37 provides a metaphorical conception, as it involves clash resolution in a secondary cognitive model profile.

\section{Conclusion}

Certain aspects of the (literal) lexical meanings of ירד (yrd) are intimately linked with perceptual mechanisms and captured by spatial representations. This study has shown that ירד (yrd) can shift meanings within different contexts of use. The shift from the literal to the metaphorical aspects of the lexical meaning of the verb ירד (yrd) involves, inter alia, image schemas found in both the linguistic system as well as the conceptual system. An important finding regarding the ancient Israelites' conceptual system is that abstract concepts are systematically structured in terms of conceptual domains deriving from their experience involving properties like motion in bodily space. The verb ירד (yrd) in Judges 11:37 is used for the conceptualisation of CHANGE in the following target domain: BEHAVIOUR. The metaphorical extensions identified are:

A LESS DESIRABLE STATE is DOWN and by implication, A MORE DESIRABLE STATE is UP.

This study offers a conceptual integrated account for the domains of motion, space and mourning and argues that the ancient Israelites' spatial cognition motivates the coding of the BEHAVIOUR-concept that is not in itself self-evidently spatial and present in many parts of linguistic structure. The significantfinding of thisstudyis that spatialconceptualisations provide the basis for non-spatial expressions in the Hebrew Bible, including behaviour.

\section{Acknowledgements}

This article is based on part of the author's PhD thesis on Spatial Cognition and the Death Metaphor in the Hebrew Bible.

\section{Competing interests}

The author declares that he has no financial or personal relationships that may have inappropriately influenced him in writing this article.

\section{Author's contributions}

A.L. is the sole author of this research article.

\section{Ethical considerations}

This article followed all ethical standards for research without direct contact with human or animal subjects.

\section{Funding information}

This research received no specific grant from any funding agency in the public, commercial or not-for-profit sectors.

\section{Data availability}

Data sharing is not applicable to this article as no data were created or analysed in this study.

\section{Disclaimer}

The views and opinions expressed in this article are those of the author and do not necessarily reflect the official policy or position of any affiliated agency of the author.

\section{References}

Bal, M., 1988, Death and dissymmetry: The politics of coherence in the Book of Judges, University of Chicago Press, Chicago, IL.

Barcelona, A., 1997, 'Cognitive linguistics: A usable approach', Cuadernos de Filología Inglesa 6(2), 9.

Briffault, R., 1927, The mothers: A study of origins and institutions of marriage, Allen \& Unwin, London. 
Bruinses, A.G., 1844, Jephta en zijne Dochter gevolgd door een viertal gewijde Taferreelen, A.L. Scholtens, Groningen.

Croft, W. \& Cruse, D.A., 2004, Cognitive linguistics, Cambridge University Press, Cambridge.

Cruse, D.A., 2004, Meaning in language: An introduction to semantics and pragmatics, Oxford University Press, Oxford.

De Blois, R., 2000, Toward a New Dictionary of Biblical Hebrew based on semantic domains, United Bible Societies, New York, NY.

De Joode, J., 2014, 'The body and its boundaries: The coherence of conceptual metaphors for job's distress and lack of control', Zeitschrift für die Alttestamentliche Wissenschaft 126(4), 554-567. https://doi.org/10.1515/zaw-2014-0035

Driver, G.R., 1957, 'On עלה "Went Up Country" and ירד "Went Down Country", Zeitschrift für die Alttestamentliche Wissenschaft 69(1-4), 74-77. https://doi. org/10.1515/zatw.1957.69.1-4.74

Evans, V., 2009, How words mean. Lexical concepts, cognitive models, and meaning construction, Oxford University Press, Oxford.

Gibbs, R.W., 2003, 'Embodied experience and linguistic meaning', Brain and Language 84(1), 2. https://doi.org/10.1016/S0093-934X(02)00517-5

Gur-Klein, T., 2003, 'Sexual hospitality in the Hebrew Bible?', Lectio Difficilior 2, 20-29.

Holladay, W.L. (ed.), 1988, A concise Hebrew and aramaic Lexicon of the Old Testament, W.B. Eerdmans, Grand Rapids, MI.

Houtman, C., 2005, 'Rewriting a dramatic Old Testament story: The story of Jephthah and his daughter in some examples of Christian devotional literature', Biblical Interpretation 13(2), 167-190. https://doi.org/10.1163/1568515053683112

Hwang, 'J.-I., Kim, G.J. \& Rizzo, A.S., 2004, 'Space extension: The perceptual presence perspective', in Conference proceedings: VRCAI 2004, ACM SIGGRAPH international conference on virtual reality continuum and its applications in industry, Nanyang Technological University, Singapore, June 16-18.

Johnson, M., 1987, The body in the mind: The bodily basis of meaning, imagination, and reason, University of Chicago Press, Chicago, IL.

Keddell, J.S., 1840, 'The vow of Jephthah', PhD dissertation, London.

Kruger, P.A., 2000, 'A cognitive interpretation of the emotion of anger in the Hebrew Bible', Journal of Northwest Semitic Languages 26, 185.

Kutsch, E., 1965, 'Trauerbräuche und Selbstminderungsriten im Alten Testament', Theologische Studien 78.

Lakoff, G., 1987, Women, fire and dangerous things: What categories reveal about the mind, University of Chicago Press, Chicago, IL.

Lakoff, G., 1992, 'The contemporary theory of metaphor', in A. Ortony (ed.), Metaphor and thought, 2nd edn., p. 4, Cambridge University Press, Cambridge.

Lakoff, G. \& Johnson, M., 1980, Metaphors we live by, Chicago University Press, Chicago, IL.

Lakoff, G. \& Kövecses, Z., 1987, 'The cognitive model of anger inherent in American English', in D. Holland \& N. Quinn (eds.), Cultural models in language and thought, pp. 195-221, Cambridge University Press, Cambridge.

Lakusta, L. \& Landau, B., 2005, 'Starting at the end: The importance of goals in spatia language', Cognition 96(1), 1-33. https://doi.org/10.1016/j.cognition.2004.03.009

Lamprecht, A., 2015, 'Spatial cognition and the death metaphor in the Hebrew Bible', Ph.D. thesis, University of the Free State.

Lang, E., Carstensen, K.-U. \& Simmons, G., 1991, 'Modelling spatial knowledge on a linguistic basis', in J. Siekmann (ed.), Lecture notes in artificial intelligence 481, p. 1 , Springer Verlag, Berlin.

Langacker, R., 1987, Foundations of cognitive grammar. Volume I: Theoretical prerequisites, Stanford University Press, Stanford.
Liptzin, S., 1985, Biblical themes in world literature, Ktav, Hoboken.

Merleau-Ponty, M., 1962, Phenomenology of perception, transl. C. Smith, Routledge \& Kegan Paul, London.

Norman, R., 2000, 'Cultivating Imagination in Adult Education,' Adult Education Research Conference, viewed n.d., from https://newprairiepress.org/aerc/2000/ papers 63.

Peleg, Y., 2013, Go you forth: The journeys of the patriarchs in the biblical narrative, Resling, Tel Aviv.

Recanati, F., 2004, Literal language, Cambridge University Press, Cambridge.

Reddy, M.J., 1979, 'The conduit metaphor - A case of conflict in our language about language', in A. Ortony (ed.), Metaphor and thought, pp. 284-324, Cambridge University Press, Cambridge.

Robinson, B.P., 2004, 'The story of Jephthah and his daughter: Then and now', Biblica 85(3), 331-348.

Rohrer, T., 2007, 'The body in space: Embodiment, experientialism and linguistic conceptualization', in T. Ziemke, J. Zlatev, F. Roz \& R. Dirven (eds.), Body, language and mind, vol. 1, pp. 340, Mouton de Gruyter, Berlin.

Rosch, E., 1973a, 'Natural categories', Cognitive Psychology 4(3), 328-350. https://doi. org/10.1016/0010-0285(73)90017-0

Rosch, E., 1973b, 'On the internal structure of perceptual and semantic categories', in T.E. Moore (ed.), Cognitive development and the acquisition of language, pp. 111-144, Academic Press, New York, NY.

Rosch, E., 1978, 'Principles of categorization', in E. Rosch \& B.B. Lloyd (eds.), Cognition and categorization, pp. 27-48, Lawrence Erlbaum, Hillsdale, NJ.

Rosenberg, A.J., 1987, Book of Judges, transl. Rashi, Judaica, New York, NY.

Sasson, J.M., 2014, 'Jephthah: Chutzpah and overreach in a Hebrew Judge', in D.S. Vanderhooft \& A. Winitzer (eds.), Literature as politics, politics as literature, pp. 405-420, Eisenbrauns, Wiona Lake, IN.

Shibayama, S., 1966, 'Notes on Yārad and 'Ālāh: Hints on translating', Journal of Bible and Religion 34(4), 358-362. https://doi.org/10.1093/jaarel/XXXIV.4.358

Sinha, C. \& Jensen de López, K., 2000, 'Language, culture and the embodiment of spatial cognition', Cognitive Linguistics 11(1-2), 17-41. https://doi.org/10.1515/ cogl.2001.008

Soggin, J.A., 1981, Judges: A commentary, Old Testament Library, SCM Press, London.

Spronk, K., 2019, 'Judges', in C. Houtman, G.T.M. Prinsloo, K. Spronk, W.G.E. Watson \& A. Wolters (eds.), Historical commentary on the Old Testament, pp. 305-358, Peeters, Leuven.

Stol, M., 1995, 'Private life in ancient mesopotamia', in J.M. Sasson (ed.), Civilizations of the ancient near East 2, vol. 1, pp. 287-297, Scribner's, New York, NY.

Sutskover, T., 2014, 'Down, up, right, and left: Directionality and space in Jonah', in A. Brenner-Idan (ed.), Discourse, dialogue, and debate in the Bible. Essays in honour of Frank H. Polak, Hebrew Bible Monographs 63, pp. 203-217, Sheffield Phoenix Press, Sheffield.

Talmy, L., 1996, 'The windowing of attention', in M.M. Shibatani \& S.A. Thompson (eds.), Grammatical constructions: Their form and meaning, pp. 235-287, Oxford University Press, Oxford.

Tyler, A. \& Evans, V., 2003, The semantics of English prepositions: Spatial scenes, embodied meaning, and cognition, Cambridge University Press, Cambridge.

Wilkens, D.P., 2006, 'Towards an Arrente grammar of space', in S.C. Levinson \& D.P. Wilkens (eds.), Grammars of space: Explorations in cognitive diversity, pp. 41-42, Cambridge University Press, Cambridge.

Wood, L.J., 1975, Distressing days of the judges, Wipf and Stock, Eugene, OR. 